Original research article

\title{
Communication competency: The topic of lifelong learning for nurse managers in hospitals
}

\author{
Jana Holá ${ }^{1 *}$, Markéta Moravcová ${ }^{2}$, Eva Hlaváčková ${ }^{1}$ \\ ${ }^{1}$ University of Pardubice, Faculty of Health Studies, Department of Clinical Subspecialities, Pardubice, Czech Republic \\ ${ }^{2}$ University of Pardubice, Faculty of Health Studies, Department of Midwifery and Health and Social Work, Pardubice, Czech Republic
}

\begin{abstract}
Background: Job satisfaction factors that are significant include managers' concern for people, their style of leadership, and management systems. For these reasons, managerial communication skills should also be an important topic included in hospital lifelong learning courses, with the ultimate goal of increasing job satisfaction. This article presents an evidence-based strategy to engage relevant stakeholders.

Methods: To monitor and rate job satisfaction, a quantitative survey inspired by the Gallup questionnaire was used. Furthermore, managers' communication skills were measured by Dewhurst and FitzPatrick's Communication Competencies Model in a quantitative survey conducted during an educational workshop. Both surveys are part of a strategy to engage relevant stakeholders in implementation of evidence-based practice step by step.

Results: The results of a job satisfaction survey initiated the decision to support efforts aiming to improve managerial communication competencies. Based on statistical analysis, the findings confirmed the existence of a discrepancy between needs and skills of the managers for all the measured competencies, thus identifying an opportunity for improvement.

Conclusions: All findings of the survey demonstrate that communication competencies are important. The model of communication competencies enabled detailed identification of which skills should be developed. The individual steps of continuous improvement correspond with the evidence-based implementation strategy and should lead to improvement of job satisfaction as part of the long-term goal.
\end{abstract}

Keywords: Communication competency; Job satisfaction; Nurse manager

\section{Introduction}

Job satisfaction has an influence on employee productivity and affects organizational efficiencies (Alromaihi et al., 2017). Indermun and Bayat's (2013) research showed the strong correlation between job satisfaction and employee performance. Job satisfaction factors that are significant include managers' concern for people, their style of leadership, and management systems etc. According to Alromaihi et al. (2017), these factors strongly affect job satisfaction and employee performance. Recently, interest in the issue of job satisfaction of healthcare professionals has been increasing, especially in the context of the continuing shortage of physicians and nurses. Medical facilities are facing the problem of how to recruit and retain qualified and motivated staff (Bártlová, 2006). Employee satisfaction affects the functioning of healthcare organizations and their results. The path leads from satisfied employees to satisfied patients, who are the main subject of interest of medical facilities. Monitoring employee satisfaction is the basis for successful human resources management; it is an important source of information and feedback for the management; it is a necessary start for improving the quality of staff.

Employee engagement is related to employee loyalty, and to a situation where employees are to some extent identified with the employer and feel a certain level of belonging to their own healthcare organization. Engagement occurs when people dedicate themselves to their work and are interested in what they do (Armstrong, 2007). According to the foreign research, employees who are fully engaged in their work and committed to their institution are more productive and usually work beyond their duties. They are satisfied with their jobs and with their superiors, and they identify with the goals and strategies of the organization (Gallup Q12 Employee Engagement Survey). According to Holá and Pikhart (2014), the quality of leadership and effective internal communication are very important for increasing employee engagement. Communication is an essential tool for managers, and managerial communication is an important part of organizational communication system. For these reasons, managerial communication skills should also be an important topic included in lifelong learning courses, with the ultimate goal of increasing job satisfaction.

\footnotetext{
* Author for correspondence: Jana Holá, University of Pardubice, Faculty of Health Studies, Průmyslová 395, 53210 Pardubice, Czech Republic; e-mail: jana.hola@upce.cz http://doi.org/10.32725/kont.2019.053

Submitted: 2019-04-18 • Accepted: 2019-10-18 • Prepublished online: 2019-10-24 
Communication is particularly significant in healthcare organizations. It follows from their specific nature - their human orientation. Communication is a principal component in the treating of patients, but also for teamwork and leadership and implementing changes (Gallagher-Ford et al., 2011). It is also one of the basic conditions for ensuring effective and quality health care and for developing healthy professional relationships (Kalish et al., 2010).

Building good relationships between the institution and the employees is one of the main features of a successful organization. It should be taken into account that employees are an important reference group that is also actively sought by the public. Engaged, satisfied and loyal employees speak well about their employer, and spread the good name of the organization, both as a medical facility and a convenient employer (Holá and Čapek, 2015). They tend to remain in the organization and show a lower rate of fluctuation. They also identify with the organization and its goals (Novotný and Pecáková, 2014). Just organizational identification is associated with job satisfaction, employee engagement and turnover intentions. A lack of organizational identification is, according to Miller (2009), associated with increased stress and burnout syndrome. Employees' identification with the organization allows for the maintaining of the internal integrity of the organization. Employees' identification with the organization also means accepting its organizational culture. Managerial communication includes all these issues - and the Dewhurst and FitzPatrick's Communication Competencies Model offers the way to improve (Wright, 2009).

Lifelong learning is considered a tool that enables healthcare professionals to obtain new information, the latest knowledge and skills, and responds to the dynamic changes in health care delivery (Bártlová, 2006). Investments in lifelong learning are therefore essential. These investments produce future returns for the organization and improve its performance (Covell and Sidani, 2013; Hamed and De Lusignan, 2013). According to Armstrong (2007), these investments also attract high-quality employees, offering them opportunities for education, development, and their careers (Aziri, 2011). They increase flexibility of employees by extending their skills, help to manage changes, create a positive organizational culture, and provide a higher level of service to customers (patients). The result is then qualified as personnel contributing to the provision of high quality and safe patient care (Covell, 2008).

Each healthcare organization provides monitoring of patient satisfaction and employee satisfaction by law. Satisfaction monitoring is one of the quality management standards. Monitoring of employee satisfaction includes monitoring their satisfaction with lifelong learning opportunities in the context of professional development and self-realization. The above mentioned is important for assessing the education system and its level in healthcare organizations. Employee satisfaction assessment of education should therefore be part of satisfaction questionnaires.

According to Gallagher-Ford et al. (2011), the strategy to engage stakeholders within implementing an evidence-based practice can be used. This strategy includes spending time and effort building trust, understanding stakeholders' interests, soliciting input from stakeholders, connecting in collaborative way, promoting active engagement in establishing metrics and outcomes to be measured. The authors cooperate on a longterm basis with 5 hospitals that were merged into one organization 5 years ago. Based on this cooperation, a job satisfaction survey was carried out. One of the results was a recommendation to increase managerial communication competencies so the top management supported communication competencies as a topic of lifelong learning through a two-year project. Within educational workshops prepared by the authors, the main communication competencies were identified, which must be further developed and embedded in the educational system for managers.

\section{Aims}

This article presents an evidence-based strategy to engage relevant stakeholders in how to improve communication skills that arose from the results of a hospital job satisfaction survey, and presents the individual steps that should lead to improvement of job satisfaction as part of the long-term goal of hospital top management teams. The sub-objectives were to monitor and rate job satisfaction, and to evaluate managerial communication competency to improve them.

\section{Materials and methods}

Two questionnaire surveys were used to collect data in quantitative research to support active involvement in establishing metrics and measuring results of managerial communication skills. Both surveys are part of a strategy to engage relevant stakeholders in the implementation of evidence-based practice step by step.

The authors were approached by top management to prepare a satisfaction assessment within the "Friendly Hospital" project - the main aim of the project was to improve the image of the hospital within the hospital. The task was to set up monitoring to identify which areas need to be strengthened. The draft of the questionnaire was discussed with the hospital top management. To monitor and rate job satisfaction, a quantitative survey inspired by the Gallup questionnaire (Gallup Q12 Employee Engagement Survey) was used. The results were presented to top management after a comprehensive survey data analysis. As a result of the identification of weak points, a recommendation was adopted to educate managers in communication competencies.

Therefore, courses for managerial communications were prepared by the authors. The most numerous group of participants comprised nurse managers who were deeply interested in the issues and continuous education in this area. After the discussion with nursing management, the Dewhurst and FitzPatrick's Communication Competencies Model (Wright, 2009) was chosen as a tool for measuring the current and required level of individual competencies. Furthermore, managers' communication skills were measured in the quantitative survey that was conducted during an educational workshop in the years 2017-2018.

\section{Survey of job satisfaction}

The data were collected in the online survey of satisfaction in the acute care hospital using an anonymous questionnaire based on standardized questionnaires of the Gallup agency. Gallup research declared engaged behaviour shows faith in the organization, spreading its good name, focus on their own work, working effort to make things better, and close cooperation with colleagues in order to improve work performance, etc. (Gallup Q12 Employee Engagement Survey).

The survey took place in December 2015 and January 2016, in a selected acute care hospital and it was addressed to all hospital staff, i.e. to the total of 4,595 employees (including 756 doctors, 3,017 non-medical health workers and 822 other employees). The sample of respondents was made up of those 
who properly filled in the entire questionnaire, which was $34 \%$ of all employees (i.e. 1,564 employees, including 174 doctors, 1,178 non-medical healthcare workers and 212 other employees).

In the survey, respondents filled out anonymous online questionnaires based on a randomly generated unique password. The questionnaires were designed according to the standardized questionnaires of the Gallup agency (Gallup $\mathrm{Q}^{12}$ Employee Engagement Survey) and surveys conducted in the project "Engagement of employees in the Czech Republic" (Novotný and Pecáková, 2014). The questionnaire contained the following selected domains of stimulants involved in the creation of job satisfaction: D1. Level of the formal setting of work; D2. Education, professional and career development; D3. Quality of the management; D4. Level of engagement and the potential for innovation and cooperation, D5. Level of self-realization; satisfaction with personal and professional development; D6. Level of belonging to the organization. The last part of the questionnaire contained the seventh domain: verification of importance of selected factors for satisfaction and improvement of organizational culture.

Each of the domains mentioned above contained several statements. There were 47 statements in the questionnaire (of which 35 statements were part of the D1 to D6 domains and 12 statements were part of the seventh section). The respondents expressed the degree of consent to the statement on a scale from 1 (definitely agree) to 5 (definitely disagree), ratings 1 and 2 were considered the positive zone for the assessment. In addition, it was possible to state the answer "I cannot judge".

The employees presented classifying characteristics in the opening part of the questionnaire. Based on these characteristics, their responses were divided into special groups: professional occupation, membership of the department, job title and length of the employment.

All questions and all domains have been statistically evaluated. The differences of evaluation of individual domains in professional groups were tested mostly by non-parametric tests (chi-square test was used to decide whether the variables (an individual statement and a professional group) in the contingency tables are dependent or not, Spearman correlation was used for confirmation of domains correlation. MannWhitney test was used to test the difference among domain evaluation.

\section{Survey of managers' communication competencies}

The survey was conducted on a sample of 102 nurses and doctors in the positions of head of department who directly manage the others and are the interface between the organisation's top management and its front-line workforce; they represent the lowest level of management within the organisational hierarchy. All of the respondents attended the 8-hour training (workshop) of managerial communication from February 2017 to March 2018. The course was voluntary and in this way the managers demonstrated their need and interest to improve their competency in this area. The workshop included a Dewhurst and FitzPatrick model (Wright, 2009), the model of 12 managerial communication competencies, and at the end of the workshop, the participants filled in a questionnaire in which they assessed their perception of importance (M) of each competency for their own work and evaluated the level of their own skills within each competency (E). Both assessments were using the Likert scale from 1 the maximum to 5 the minimum. The competency was defined as the ability to do something successfully or efficiently. The lower the number, the more positive the rating.
The Dewhurst and FitzPatrick model (Table 1) uses a list of 12 communication competencies for a competent communicator. Each name of competency has its abbreviation for the time it is next used.

These competencies should help the managers to understand their managerial skills in communication and should help them to set their own communication in order to evaluate and develop it. The authors describe each competency in 3 levels - basic, intermediate and advanced, and they describe ineffective behaviour for better understanding and to offer the way towards improvement. These competencies create a useful framework for the development of managerial communication competencies.

\begin{tabular}{|c|c|}
\hline Competency & Competency \\
\hline 1 Building effective relationships & 7 Innovation and creativity \\
\hline 2 Business focus & 8 Listening \\
\hline 3 Consultation and coaching & 9 Making it happen \\
\hline 4 Cross functional awareness & 10 Planning \\
\hline 5 Craft (writing and design) & 11 Specialist \\
\hline 6 Developing other communicators & 12 Vision and standards \\
\hline
\end{tabular}

\section{Results}

Table 2 shows the main results of the job satisfaction survey. The table presents the evaluation of individual domains (D1D6) in the professional group of doctors, non-medical healthcare personnel and other employees. Positive evaluation (i.e. 1 and 2) by non-medical healthcare personnel is presented only in the domains 1 - level of the formal setting of work. All other domains reached average values greater than 2 in the evaluation. The weakest rating is in domain 6 - level of belonging to the organization. It uncovers instability of the staff, which could disrupt the functioning of the whole organization in the future, because as the most important source of information in the organization, an employee spreads its reputation towards patients and potential employees and significantly affects the public relations of the organization and its image.

$\begin{aligned} & \text { Table 2. The average value of each rated domain* in the } \\
& \text { professional categories }\end{aligned}$
\begin{tabular}{lccccccc} 
Professional group & D1 & D2 & D3 & D 4 & D5 & D6 \\
\hline $\begin{array}{l}\text { Doctors } \\
\text { Non-medical health- }\end{array}$ & 1.953 & 2.000 & 2.393 & 2.517 & 2.292 & 2.819 \\
$\begin{array}{l}\text { care personnel } \\
\text { Other employees }\end{array}$ & 1.805 & 2.442 & 2.402 & 2.519 & 2.150 & 2.465 \\
Total & 1.776 & 2.218 & 2.385 & 2.484 & 2.218 & 2.668
\end{tabular}

* Domains: D1 Level of the formal setting of work; D2 Education, professional and career development; D3 Quality of the management; D4 Level of engagement and the potential for innovation and cooperation, D5 Level of self-realization; satisfaction with personal and professional development; D6 Level of belonging to the organization. 
All of the employees rate the domains D2 - education, professional and career development and D5 - the level of self-realization, satisfaction with personal and professional development as the second best (average rating 2.218). A professional group of doctors assesses this domain as the best (average rating 2.000). Other employees assess this domain as the worst (average rating 2.442). D3 - quality of the management gained 2.385 .

We can see from the results in table 3 that the strongest correlation is between the domains D2 - education, professional and career development and D5 - the level of self-realization, satisfaction with personal and professional development (correlation coefficient 0.72). Educational events and their sufficient offer enable professional growth and the realization and development of employees' personal abilities. They improve not only the individual performance but also the performance of the whole organization, for example in the form of better productivity and quality of provided health services.

Table 3 shows the values of the correlation coefficients. All coefficients are statistically significant, which means all domains correlate together. Domain D2 also has a strong correlation to domain D3 - the quality of management (correlation coefficient 0.68 ). Good management creates the suitable conditions for work, supports and plans employee education and gives hospital staff enough education opportunities. The stronger correlation is between D3 - the quality of management and D5 - the level of self-realization, satisfaction with personal and professional development - and this domain has the stronger correlation with D6. That may confirm the meaning of quality of management which affects self-realization, engagement and loyalty.
Table 3. The correlations between domains expressed by Spearman's correlation coefficient

\begin{tabular}{lcccccc} 
Domains* $^{*}$ & D1 & D2 & D3 & D4 & D5 & D6 \\
\hline D1 & 1.00 & 0.44 & 0.46 & 0.42 & 0.53 & 0.51 \\
D2 & 0.44 & 1.00 & 0.68 & 0.55 & 0.72 & 0.57 \\
D3 & 0.46 & 0.68 & 1.00 & 0.61 & 0.79 & 0.57 \\
D4 & 0.42 & 0.55 & 0.61 & 1.00 & 0.66 & 0.61 \\
D5 & 0.53 & 0.72 & 0.79 & 0.66 & 1.00 & 0.70 \\
D6 & 0.51 & 0.57 & 0.57 & 0.61 & 0.70 & 1.00 \\
\hline
\end{tabular}

* Domains: D1 Level of the formal setting of work; D2 Education, professional and career development; D3 Quality of the management; D4 Level of engagement and the potential for innovation and cooperation, D5 Level of self-realization; satisfaction with personal and professional development; D6 Level of belonging to the organization.

Table 4 shows the result of managerial communication competencies results. The table presents an assessment of each competency by the managers. The competency order is the same as in table 1 , using the abbreviations ' $M$ ' for importance and ' $E$ ' for evaluation. All of the evaluated competencies are described by statistics: mean, median, total sum, variance.

All statistics provide a clear comparison of a competency evaluation among themselves and a comparison of managerial perception of importance (M) and an evaluation of skills in each of them (E). Variance shows the managers' consensus (the smaller the value, the greater the consensus). The last column of table 4 contains the difference between the evaluation

Table 4. Descriptive statistics of competence evaluation

\begin{tabular}{|c|c|c|c|c|c|c|}
\hline Variables & $N$ & Mean & Median & Sum & Variance & Difference \\
\hline $1 \mathrm{M} /$ Building effective relationships & 102 & 1.196078 & 1.000000 & 122.0000 & 0.159192 & \\
\hline 1E/ Building effective relationships & 102 & 1.950980 & 2.000000 & 199.0000 & 0.443118 & 0.754902 \\
\hline 2M/ Business focus & 102 & 1.784314 & 2.000000 & 182.0000 & 0.269851 & \\
\hline 2E/ Business focus & 102 & 2.009804 & 2.000000 & 205.0000 & 0.504853 & 0.225490 \\
\hline 3M/ Consultation and coaching & 102 & 1.647059 & 1.500000 & 168.0000 & 0.527665 & \\
\hline 3E/ Consultation and coaching & 102 & 2.215686 & 2.000000 & 226.0000 & 0.646088 & 0.568627 \\
\hline $4 \mathrm{M} /$ Cross functional awareness & 102 & 1.735294 & 2.000000 & 177.0000 & 0.394584 & \\
\hline 4E/ Cross functional awareness & 102 & 2.166667 & 2.000000 & 221.0000 & 0.437294 & 0.431373 \\
\hline $5 \mathrm{M} / \mathrm{Craft}$ & 102 & 1.901961 & 2.000000 & 194.0000 & 0.505145 & \\
\hline $5 \mathrm{E} / \mathrm{Craft}$ & 102 & 2.107843 & 2.000000 & 215.0000 & 0.295185 & 0.205882 \\
\hline $6 \mathrm{M} /$ Developing other communicators & 102 & 1.931373 & 2.000000 & 197.0000 & 0.559600 & \\
\hline 6E/ Developing other communicators & 102 & 2.196078 & 2.000000 & 224.0000 & 0.357212 & 0.264706 \\
\hline $7 \mathrm{M} /$ Innovation and creativity & 102 & 1.833333 & 2.000000 & 187.0000 & 0.239274 & \\
\hline 7E/ Innovation and creativity & 102 & 2.352941 & 2.500000 & 240.0000 & 0.527665 & 0.519608 \\
\hline 8M/Listening & 102 & 1.382353 & 1.000000 & 141.0000 & 0.416715 & \\
\hline 8E/Listening & 102 & 1.705882 & 2.000000 & 174.0000 & 0.506698 & 0.323529 \\
\hline 9M/ Making it happen & 102 & 1.578431 & 2.000000 & 161.0000 & 0.345273 & \\
\hline 9E/ Making it happen & 102 & 1.931373 & 2.000000 & 197.0000 & 0.599204 & 0.352941 \\
\hline 10M/Planning & 102 & 1.539216 & 2.000000 & 157.0000 & 0.250922 & \\
\hline 10E/Planning & 102 & 2.068627 & 2.000000 & 211.0000 & 0.361580 & 0.529412 \\
\hline $11 \mathrm{M} /$ Specialist & 102 & 1.392157 & 1.000000 & 142.0000 & 0.339740 & \\
\hline 11E/ Specialist & 102 & 1.852941 & 2.000000 & 189.0000 & 0.522714 & 0.460784 \\
\hline $12 \mathrm{M} /$ Vision and standards & 102 & 1.774510 & 2.000000 & 181.0000 & 0.473403 & \\
\hline 12E/Vision and standards & 102 & 2.186275 & 2.000000 & 223.0000 & 0.568919 & 0.411765 \\
\hline
\end{tabular}


of managerial importance and the skill of each competency. The managers marked the competency 'Building effective relationships' as the most important meaning competency for managers' performance (the lowest mean and sum). This competency gained the biggest difference between the importance and the managers' own evaluation.

When assessing this competence, the managers also showed the greatest consensus (the smallest variance). On the contrary, the managers assessed developing other communicators as the least important of their competencies; this competence gained the largest amount (240). Each assessment of importance competency gained a lower mean than 2 and a median of a maximum 2 . This result shows the managers consider each competency important for their own performance. The evaluation of managers' own communication competencies was different for each competency. The competency 'Craft' gained the smallest difference. Managers best rated their own competency as 'Listen' and they marked the worst ranked competency as 'Innovation and creativity'. All differences were tested for statistical significance $(\alpha=0.05)$ by the nonparametric Wilcox test. All differences were significant.

\section{Discussion}

Managers are responsible for team results and the attitude towards work shown by the team members. Managers are different from other employees and have become leaders because of their responsibility and competence, i.e. authority, knowledge, skills, abilities, and experience.

It is necessary to highlight that managerial communication arises from the attitudes and opinions of the individual managers, which are a reflection of the attitudes, and opinions of the organization. Styles of leadership based on leaders' communication strongly influences job satisfaction (Alromaihi et al., 2017). The managers should be educated in communication competencies (Vermeir et al., 2015).

The results of the job satisfaction survey data analysis show that for $82 \%$ of employees, lifelong learning is necessary. Lifelong learning is very beneficial to $74 \%$ of employees, but only $55 \%$ of them agree that they have enough education opportunities, and only $48 \%$ claim that their superior regularly talks to them about their professional development.

Doctors show a greater interest in lifelong learning and consider it more beneficial than the other professional groups. They are followed by non-medical health care personnel and other employees. Other employees are the most dissatisfied with the opportunities for education and assess the possibility to talk with their superior about their further professional development the worst. On the contrary, non-medical health care personnel evaluate these areas from all three professional groups the best.

It would certainly be necessary to assess the educational activities in the last periods in more detail in order to verify which topics would be appropriate and to continue supporting them. From the point of view of the survey results, it is necessary to focus on the internal educational system and the conditions for the further increasing of qualifications by creating educational opportunities. This recommendation is supported by several studies. According to Vermeir et al. (2015), the support of educational opportunities is one of the most important reasons for a decision to remain in the hospital. The authors state in their article that communication between caregivers and the importance as well as quality - should be embedded in postgraduate training to become an essential skill and quality characteristic of each caregiver. As Bártlová (2006) presents, professional development and education are important factors that increase the stability of medical staff and affect loyalty to the organization. The availability of educational opportunities and their support by management also contributes to job satisfaction and create a positive social climate in the workplace (Putra, 2019). Ensuring quality education by management also has a significant impact on patient satisfaction, the length of employment, reduced incidence of complications, decreasing mortality etc. It also may be related to better education of patients and better medical documentation (Covell, 2008).

A competent manager is a person who is able to use the right competencies and thus be the right manager. The model of 12 competencies creates the frame for managerial development as well. It is also crucial to assess and evaluate the current state of competencies of the particular manager and then create a personal development plan for them.

All findings of the survey illustrate how the communication competencies are important and there is space for their development and improvement. The Dewhurst and FitzPatrick's Communication Competencies Model can show in detail which skills must be developed more or less. These findings are very important for survey participants and for their top management.

The personality of a manager is the most significant influence over their communication and, to improve it, it is necessary for managers to accept their own responsibility for communication (Vermeir et al., 2015).

Managers must be fully aware that their messages present certain ideas and the understanding of those ideas is fully dependent on the way they are transferred to other people. Communication transfer not only influences how the information is passed to other people, but also whether those other people understand it in the way that it was intended (Holá and Pikhart, 2014). In addition, of course, it is necessary to take into account the communication channel that can distort the message. Therefore, in the end, it is necessary to check if the transfer was successful, i.e. that the information has been understood.

Managerial competencies, however, are only one part of the building elements of the internal communication system. This system must be complied. Holá and Pikhart (2014) offer one of the ways of internal communication system setup. The design of the system is based on concrete prerequisites for functioning internal communication (strategic organisational culture, unified team of company leaders, social policy, communication competencies of managers, formal communication, communication standards, internal PR, open communication).

All of these points can only be entirely effective if the communicator is willing to take on partnership and trust. If the manager is not able to accept these basic principles of open communication, these competencies and skills will not be permanent and communication will fail (Smith, 2008).

From the above-mentioned, it can be clearly seen that managers' communication consists of a cluster of various activities, namely: personnel management, internal marketing and the direct management of teams and their members. It is a vast field of human effort being performed at least in these three defined levels (Holá and Čapek, 2015).

The survey of job satisfaction provided evidence that managerial communication is an important issue and that it is also a required topic of personnel development - so it should be embedded into long-life learning. Both surveys are part of a strategy to engage relevant stakeholders in implementation of evidence-based practice step by step. This strategy helps imple- 
menting an evidence-based practice change (Gallagher-Ford et al., 2011). In this case, top management accepts managerial communication as an important issue because evidence based on the results of the survey was presented and discussed with stakeholders. Nurse managers accepted the model of Dewhurst and FitzPatrick and recommended this topic be included in hospital lifelong learning courses.

\section{Conclusions}

The results of both surveys confirm the importance of managerial communication competency as an important topic of lifelong learning in the company. The influence of quality of management on employee satisfaction strongly emphasizes the importance of managerial communication. All of the statistics provide a comparison of competency evaluation among themselves, and a comparison of managerial perception of importance (M) and evaluation of their own skills of each competency. The managerial perception of the importance of expressing their need to master this competency and their own evaluation of skills shows a gap in lifelong education. The survey of employee satisfaction shows that lifelong learning is important and beneficial to hospital employees.

The shortage of lifelong learning opportunities may negatively affect the professional development area, and a lack of managerial competencies causes a reduction in employee motivation. Based on the survey results, we recommend preparing and implementing a uniform education concept of internal education of managers. No manager who attended communication training and participated in the survey had any previous managerial qualification. They were promoted to the management position without the required managerial education. Managerial education is not required as a qualification for managers. Their qualifications must comply with statutory qualification requirements. All of the competencies of their professional performance are defined by law. The managerial competencies are not defined; hospitals are still searching for the suitable model of managerial competencies. It is necessary to improve not only the communication competencies of managers - the entire internal communication system needs to improve too. Communication is based on several layers and their interaction is crucial for success - their concord and harmony is the only key to better performance and efficiency.

The survey findings also provide a good base for setting a model of managerial competencies, which will be created to unify the model of managerial competencies. At present, much more emphasis is put on the professional competencies associated with providing care rather than managerial. Therefore, the authors include communication skills in the competency model within the "Competent Nurse of the 21st Century". Managerial competencies for doctors and paramedical staff are not described and defined, although the importance of managerial communication and its impact on employee engagement and quality of their work is evidence based.

\section{Conflict of interests}

The authors have no conflict of interests to declare.

\section{Funding}

This research was funded by the Technology Agency of the Czech Republic, grant number TL01000094.

\title{
Komunikační kompetence: téma celoživotního vzdělávání všeobecných sester manažerek v nemocnicích
}

\begin{abstract}
Souhrn
Úvod: Významnými faktory, které ovlivňují spokojenost v zaměstnání, jsou mimo jiné manažerské vedení a řízení, resp. manažerský styl, péče o zaměstnance a systém řízení. Proto by v rámci zvyšování spokojenosti zaměstnanců měly být manažerské komunikační dovednosti jedním z významných témat celoživotního vzdělávání manažerů v nemocnici stejně jako v kterékoliv jiné organizaci. Tento článek představuje nastavení tématu manažerských komunikačních kompetencí do rámce celoživotního vzdělávání s využitím na důkazech založené strategie zapojení všech zainteresovaných stran.

Metody: Ke sledování a hodnocení spokojenosti v zaměstnání byl použit kvantitativní průzkum inspirovaný dotazníkem organizace Gallup. Komunikační kompetence manažerů byly následně ověřovány během vzdělávacího workshopu, a to pomocí modelu komunikačních dovedností Dewhursta a FitzPatricka. Oba průzkumy byly součástí strategie zapojení zúčastněných stran, která pracuje s důkazy jako argumenty pro zapojení všech relevantních účastníků do procesu dosažení jednotného cíle.

Výsledky: Výsledky průzkumu spokojenosti zaměstnanců podnítily rozhodnutí podpořit úsilí zaměřené na zlepšení manažerských komunikačních dovedností. Statistická analýza potvrdila rozdíl mezi potřebami a dovednostmi manažerek z řad všeobecných sester, čímž identifikovala příležitost ke zlepšení a podložila zařazení tohoto tématu do celoživotního vzdělávání.

Závěr: Všechna zjištění průzkumů ukazují, že manažerské komunikační dovednosti všeobecných sester jsou významné. Konkrétní model komunikačních kompetencí umožnil podrobně identifikovat potřeby rozvoje jednotlivých kompetencí. Pro nastavení tématu celoživotního vzdělávání byla využita implementační strategie všech zainteresovaných stran (zaměstnanci, management střední i top management), která by měla vést k dosažení společného dlouhodobého cíle: zvyšování spokojenosti zaměstnanců.
\end{abstract}

Klíčová slova: komunikační dovednosti; spokojenost v zaměstnání; všeobecná sestra manažerka

\section{References}

1. Alromaihi AM, Alshomaly ZA, Geore S (2017). Job satisfaction an employee performance: a theoretical review of the relationship between the two variables. IJARMSS 6(1): 1-20.

2. Armstrong M (2007). Rízení lidských zdrojů: nejnovější trendy a postupy. Praha: Grada.
3. Aziri B (2011). Job satisfaction: a literature review. Manag Res Pract 3(4): 77-86.

4. Bártlová I (2006). Pracovní spokojenost zdravotních sester v České republice. Zdravotnictví v České republice, 9(4): 166-169.

5. Covell C (2008). The middle-range theory of nursing intellectual capital. J Adv Nurs 63(1): 94-103. DOI: 10.1111/j.13652648.2008.04626.x. 
6. Covell C, Sidani S (2013). Nursing intellectual capital theory: testing selected propositions. J Adv Nurs 11(69): 2432-2445. DOI: 10.1111/jan.12118.

7. Gallangher-Ford L, Fineout-Overholt E, Melnyk BM, Stillwell SB (2011). Implementing an evidence-based practice change. Am J Nurs 111(3): 54-60. DOI: 10.1097/10.1097/01. NAJ.0000395243.14347.7e.

8. Gallup Q12 Employee Engagement Survey. [online] [cit. 201804-03]. Available from: https://q12.gallup.com/public/en-us/ Features

9. Hamed H, De Lusignan S (2013). Literature review: the role of intangible resources in improving quality of care in hospitals. In: Green A (Ed.). Proceedings of the international conference on intellectual capital, knowledge management, pp. 514-523.

10. Holá J, Čapek J (2015). Evaluation of the Relevance and Effectiveness of the Internal Communication Elements. In Proceedings of the 12th International Conference Liberec Economic Forum, pp. 161-169.

11. Holá J, Pikhart M (2014). The implementation of internal communication system as a way to company efficiency. E+M Economics and Management. Liberec: EF TU. DOI: 10.15240/ tul/001/2014-2-012.

12. Indermun V, Bayat M (2013). The Job Satisfaction-Employee performance relationship, a theoretical perspective. IJIREM 11(2): 1-9.
13. Kalish BJ, Lee H, Rochman M (2010). Nursing Staff teamwork and Job Satisfaction. J Nurs Manag 18(8): 938-947. DOI: 10.1111/j.1365-2834.2010.01153.x.

14. Miller K (2009). Organizational communication. Approaches and processes. Boston: Wadsworth.

15. Novotný O, Pecáková I (2014). Angažovanost zaměstnanců v ČR. Výzkumná zpráva. Praha: VSE.

16. Putra TR (2019). The role of organizational climate and work motivation on job satisfaction in ACEH Government Health Office. J Acad Res Econom 11(1): 98-106.

17. Smith L (2008). Effective Internal Communication. London: Kogan Page.

18. Vermeir P, Vandijck D, Degroote S, Peleman R, Verhaeghe R, Mortier E, et al. (2015). Communication in healthcare: a narrative review of the literature and practical reccomendations. Int J Clin Pract 69(11): 1257-1267. DOI: $10.1111 / \mathrm{ijcp} .12686$.

19. Wright M (2009). Gower Handbook of Internal Communication. Dewhurst and FitzPatrick's Communication Competencies Model. Farnham: Gower Publishing Limited. 